\title{
KASVATUKSELLA LUODAAN MAAILMAA, JOSSA ON HELPOMPI RAKASTAA
}

OLIN TOISEN TAI KOLMANNEN vuoden kasvatustieteiden opiskelija, kun luin Sorrettujen pedagogiikan ensimmäistä kertaa. Olin vanhempieni kesämökillä, ja kesäpäivä oli kaunis. Vaikutuin Paulo Freiren kauniista kielestä ja uskosta ihmisyyteen, ja vakuutuin siitä, että kasvatus todella on maailman tärkein asia ja olen onnekas, kun saan opiskella sitä teoreettisesti. Yleisen ja aikuiskasvatustieteen opiskelijana podin nimittäin melko usein tuskaa siitä, mihin tämä kaikki minua veisi. Katselinkin tuona viikonloppuna tuttua maisemaa vähän eri silmin kuin aiemmin.

Suuntauduin uralleni generalistin tavoin melko perinteisesti sattuman kautta. Tein harjoitteluni järjestökentällä ja suuntauduin osallisuuden edistämisen ja työllisyydenhoidon kentille. Työn fokus oli siten nuorten ja aikuisten oppimisessa. Sain tehdä töitä niin politiikkasuositusten eteen kuin ruohonjuuressa toimien. Huomasin, että työn arjessa ja tulostavoitteiden puristuksessa ei aina ehditä pohtia kattavasti työn arvolähtökohtia ja ihmiskuvaa koskevia sitoumuksia. Opintoni antoivat tähän onneksi välineitä.

Brasilialainen kasvatusfilosofi Paulo Freire (19211997) tunnetaan ennen kaikkea kriittisen pedagogiikan laatijana. Sorrettujen pedagogiikassa hän vaatii vallankumousta: yhteiskunnallisten valta-asetelmien purkamista. Opiskelijana muistan epäilleeni, miten realistisia hänen ajatuksensa olivat. Miten siinä kävisi, jos oikeasti tähtäisimme vallankumoukseen?

Freire korostaa, että vallankumous ei saa johtaa siihen, että sorretut nousevat valta-asemiin ja alkavat vuorostaan sortaa muita. Mutta miten tämä on käytännössä mahdollista? Eikö eri ryhmien edut ole aina väistämättä ristiriidassa keskenään? Freire myös vastaa epäilyksiini pääteoksessaan, kuten myöhemmin oivalsin.

SYKSYLLÄ 2018 päädyin kehittämään aikuisten perustaito-opetusta Kansanvalistusseurassa, maan vanhimmassa sivistyssäätiössä. Kansalaisen perustaidot -hankkeessa luodaan yhdessä Opintokeskus
Siviksen kanssa vaikuttavaa opetusmallia aikuisille. Aloitin pohtimalla toimeksiantoa hahmottelemalla ja purkamalla auki määritelmiä ja toiminnan luonnetta. Oli tärkeää sanoittaa elinikäisen oppimisen lähtökohta ihmisen oman potentiaalin käyttämisen ja kehittämisen tehtävänä. Kun opetamme perustaitoja aikuisille, tulee ensin määritellä, mitä tarkoitamme perustaidoilla ja miten niitä tulee teoriassa ja käytännössä opettaa.

Tuolloin palasin Freiren pariin ja havaitsin hänen ajatuksensa ajankohtaisiksi ja hyödyllisiksi.

Freire kirjoittaa, että epäinhimillistäessään muita sortaja epäinhimillistää myös itsensä. Kun hän kahlitsee sortoon heikossa asemassa olevat, hän kahlitsee itsensä ulos siitä, mikä tekee ihmisestä ihmisen. Hänestä tulee materiaalisten olojen vanki, hänen olemisestaan tulee omistamista. Näin vapautuminen sorrosta vapauttaa niin sorretut kuin sortajatkin. (Freire 2016, 44.)

FREIREN SANOMAN PERUSTA on riipaisevan vankkumaton usko ihmisen perimmäiseen hyvyyteen. Olen eri yhteyksissä törmännyt siihen perusteluun, että mikään yhteinen pyrkimys ei voi toimia, koska "ihminen on perusluonteeltaan itsekäs". Mutta itse en ole koskaan ajatellut niin. Olen kiitollinen Freirelle, että hän purkaa auki sen, mistä itsekäs käytös ja ahneus kumpuavat: ihmisryhmien dehumanisoinnista. Se tuottaa vääränlaisia uskomuksia ja arvoja ja sen individualistisen käsityksen, että voi olla vain joko häviäjä tai voittaja. Pikemminkin on niin, että ihmisiä eriarvoistavassa pelissä ei ole voittajia.

Freiren ajattelun toinen perustava lähtökohta on ihmisten tasa-arvoisuus. Perinteisesti pedagogiseen suhteeseen on kuvattu sisältyvän opettajan ja oppijan välinen hierarkkisuus. Freirelta tätä ajatusta ei löydä, vaan hänelle opettaminen on dialogiin antautumista (Freire 2016, 97). Sitäkin sulattelin nuorena: Miten muka oppija voisi ymmärtää omia oppimistarpeitaan? Eikö opettaja olekaan vastuussa siitä, että oppijat oppivat sen, mitä heidän tarvitsee pärjätäkseen systeemissä? 
EPÄINHIMILLIST ̈̈ESS $\ddot{A}$ ÄN MUITA SORTAJA EPÄINHIMILLISTÄ̈̈ MYÖS ITSENS $\ddot{A}$.

FREIREÄ ON ARVOSTELTU patriarkaalisesta maailmankuvasta. Feministipedagogi bell hooks tuo kuitenkin Vapauttava kasvatus -kirjassaan esiin sen, miten hänenkin opettajanaan toiminut Freire ei väheksynyt feminististä pyrkimystä vaan kuulutti sen taiston kävijöiksi naisia. Naisten kamppailu kuuluu Freiren mukaan silti myös miehille. (hooks 2007, 100-101). Sorrettujen tehtäväksi jää vapauttaa niin itsensä kuin sortajatkin, ja tämän tulee tapahtua sortajien tuella (Freire 2016, 58).

Sorrettujen pedagogiikassa Freire kiteyttää sanomansa: " Toivon, että seuraavat sivut välittäisivät ainakin luottamukseni ihmisiin ja uskoni ihmiseen ja sellaisen maailman luomiseen, jossa on helpompi rakastaa. (Freire 2016, 42).

Freire uskoo, että tavalliset ihmiset voivat muuttaa maailmaa, jos he ymmärtävät olevansa yhdenvertaisia kaikkien muiden ihmisten kanssa, eivätkä ota annettuina olemassa olevia oloja. Kulttuuri ja muutos ovat ihmisten luomia. Kasvatuksen tehtävä ei ole sopeuttaa ihmisiä vallitsevaan järjestelmään vaan muuttaa järjestelmää yhä tasa-arvoisemmaksi yhdessä ihmisten kanssa. Problematisoivassa kasvatuksessa pyritään vahvistamaan oppijan kriittistä tietoisuutta sen sijaan, että oletettaisiin maailma valmiiksi ja odotettaisiin opittavan ulkoa valmiit sisällöt. Jälkimmäistä, kritiikitöntä lähestymistä Freire kutsuu tallettavaksi kasvatukseksi. (Freire 2016, 75).

Tallettavan kasvatuksen sijaan Freire kannattaa sitä, että oppijat otetaan mukaan opetuksen suunnitteluun. Politics of Education -teoksessaan hän ehdottaa, että oppimateriaaleja koostetaan yhdessä oppijoiden kanssa. Esimerkiksi lukutaitokampanjoiden oppijat voisivat osallistua materiaalin tuottamiseen. Heidän puhettaan nauhoitettaisiin, ja äänitteitä käytettäisiin koulutusmateriaalina, jota kommentoitaisiin vertaisten toimesta ja työstettäisiin edelleen myös kirjalliseen muotoon. Näin voidaan kehittää

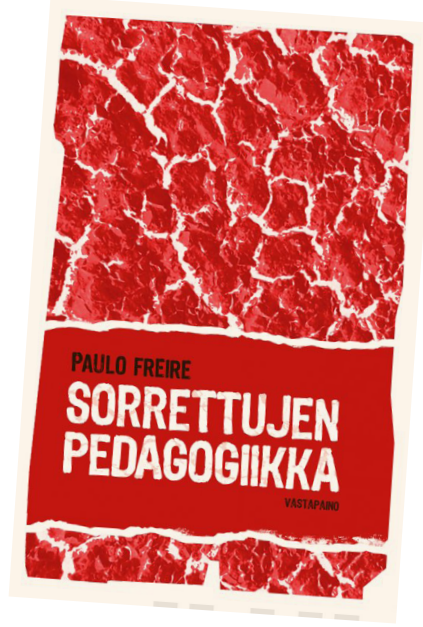

Paulo Freiren klassikkoteos ilmestyi suomeksi ensimmäisen kerran vuonna 2005.

oppijoiden itseilmaisua. (Freire 1985, 27.)

Freirelle lukutaitoisuus tai -taidottomuus eivät koskaan ole yksilön valintoja, saati merkkejä älykkyydestä tai sen puutteesta. Lukutaidottomuus johtuu joko siitä, että ihminen ei ole elinympäristössään tarvinnut lukutaitoa tai se on evätty häneltä (Freire 1985, $7-8,13$.) Kyse on tällöin rakenteista ja politiikasta. Ajatus on ajaton. Ensinnäkin osaaminen ja tarvittavat tiedot ja taidot ovat tilanne- ja kulttuurisidonnaisia, ja niiden kehittyminen ja tarve ovat suhteessa ympäristöön. Toiseksi perustaitojen, esimerkiksi lukutaidon, oppiminen nähdään oikeutena. Jos ihminen ei ole saanut tilaisuutta oppia omassa elinympäristössään keskeisiä taitoja, kyse on todellisten mahdollisuuksien puuttumisesta, sorrosta.

Freiren ajattelun punainen lanka on yhteiskunnallisen epäoikeudenmukaisuuden ja sorron vastustaminen. 'Sorrolla' hän tarkoittaa esteitä, jotka rajoittavat mahdollisuuksia omaehtoisuuteen ja toimintaan vastuullisena ihmisenä (Freire 2016, 57). Se on näin alistettuihin ihmisiin kohdistettua valtaeliitin tyranniaa. Sorto voi kohdistua ryhmiin, kuten luokkaan, sukupuoleen, köyhiin, etnisiin vähemmistöihin, sukupuolivähemmistöihin, siirtolaisiin, paperittomiin tai psyykkisesti tai fyysisesti vammautuneisiin. (Suoranta 2019, 16.) 
Freire käsittää lukutaidon kyvyksi katsoa ja arvioida maailmaa kriittisesti, ei mekaaniseksi kyvyksi toistaa sanoja. Kriittinen ja ymmärrykseen tähtäävä lukutaito mahdollistaa oman paikan ottamisen maailmassa ja uuden luomisen. (Freire 1985, 14-15.) Opetuksen tulee siis kasvattaa oppijoiden kykyä kriittiseen ajatteluun ja tietoisuutta omista oikeuksista.

Freiren kasvatusajattelua voi soveltaa muihinkin perustaitoihin kuin hänen painottamaansa lukutaitoon. Perustaitojen puute heikentää yksilön mahdollisuuksia käyttää ja kehittää täyttä potentiaaliaan, mistä seuraa ongelmia yksilön hyvinvoinnille ja omaehtoiselle toimimiselle yhteiskunnassa. Digitalisoituneessa yhteiskunnassa perustaitojen pitäminen ajan tasalla tuottaa uusia oppimistarpeita jokaiselle.

OLEN TYÖSKENNELLYT VUODEN ajan Kaikkienmalliksi kutsutun opetusmallin parissa. Sen tavoitteena on toteuttaa perustaito-opetusta oppijalähtöisesti, arjen haasteita ratkaisemalla. Ollakseen pedagogisesti vaikuttava mallin on oltava oppijaa sitouttava ja motivoiva. Freiren ajatukset oppijoiden yhdenvertaisuudesta ja oppimiseen motivoitumisesta ovat olleet työskentelyssä tärkeitä ja toimivia.

Oleellista on yhtäältä tunnustaa, että jokaisella on tietoja ja taitoja, mutta toisaalta tarvitsemamme kompetenssit muuttuvat suhteessa ympäristöömme. Jokaisella on siten osaamisen lisäksi puutteita taidoissa uusissa ympäristöissä tai tilanteissa toimiessaan. Jotta oppiminen olisi motivoivaa ja vaikuttavaa, opetustilanteessa tulee tunnistaa ja tunnustaa yksilön tiedot ja osaaminen ja selvittää, mikä on hänen kannaltaan oleellista. Opetus ja kasvatus eivät siten voi suuntautua ylhäältä alaspäin.

Freire oli sitoutunut maailman muuttamiseen ja painotti käytännön työskentelyä teoreettisten pohdintojen rinnalla. Hän ymmärsi oppijat tasa-arvoisiksi toimijoiksi ja oppimisen yhdessä tekemiseksi. Opettaja tai ohjaaja on itsekin mukana oppimassa. Sisältöjen tulee olla oppijoille itselleen tarpeellisia.

Aikuisten perustaitojen opetukseen sovellettuna Freiren ajattelusta nousevat periaatteiksi oppijalähtöisyys, paikallisuus ja perustaitojen kehittäminen toiminnassa. Paikallisuus tarkoittaa toiminnan kytkemistä oppijan omaan fyysiseen ja sosiaaliseen ympäristöön. Perustaitojen nähdään kehittyvän oppijan oman elämän tarpeesta nousevien ongelmien ratkaisemisesta käsin. Nämä ovat hankkeessamme toteutettavien koulutuspilottien sekä hankkeen lopputuloksena luodun Kaikkien-mallin ydinperiaatteita, joiden haluamme näkyvän käytännön työssä.

Paulo Freiren ansiosta tiedän, että huomisen maailma luodaan tässä hetkessä, tiedostaen tai tiedostamatta, valtarakenteita pönkittäen tai purkaen. Ihmisiä rakenteellisesti eriarvoistaen ja sortaen tai -vaihtoehtoisesti - luoden maailmaa, jossa jokaisen meistä on helpompi rakastaa.

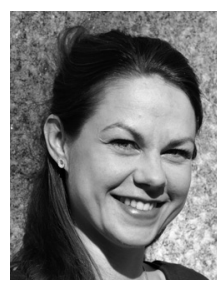

KM, koulutussuunnittelija Kansanvalistusseura

\section{LÄHTEET}

Freire, P. (1996). Pedagogy of the Oppressed. London: Penguin Books Ltd.

Freire, P. (2016). Sorrettujen pedagogiikka. Suom. J. Kuortti. Toim. T. Tomperi. Tampere: Vastapaino.

Freire, P. (1985). The Politics of Education. Culture, Power, and Liberation. Westport, CT: Bergin \& Garvey Publishers, Inc. hooks, bell. (2007). Vapauttava kasvatus. Helsinki: Kansanvalistusseura.

Suoranta, J. 2019. Paulo Freire. Sorrettujen pedagogi. Helsinki: Into. 